\title{
STRATEGI DAN PERSAINGAN PERGURUAN TINGGI SWASTA
}

\author{
Budiyono dan Sri Laksmi Pardanawati \\ STIE AAS Surakarta
}

\begin{abstract}
To face the competition of private universities must have the appropriate strategies Strategies that can give direction to the organization to face challenges and threats that arise in the present and the future taking into account its strengths and weaknesses.
\end{abstract}

Keywords: Strategy and Competition 


\section{PENDAHULUAN}

Dalam persaingan global,dimana perubahan lingkungan bisnis yang terjadi berlangsunag dengan cepat dan dinamis.Para pelaku bisnis dihadapkan pada pilihan untuk menciptakan keunggulan produk,pengembangan pasar, inovasi yang memuaskan pelanggan dan perkembangan suatu bisnis

Semua itu dapat dicapai dengan peningkatan kualifikasi dan pemahaman yang baik dari Sumber Daya Manusia, Perusahaan terhadap lingkungan bisnis,strategi Usaha ,rencana pemasaran ,Inovasi Produk dan layanan yang prima.

Untuk menjawab kebutuhan Sumber Daya Manusia yang Handal,Profesional,berintegritas.Akademi Akuntnsi Surakarta (AAS) menjawab dan memberikan solusi dengan membuka program Diploma III Akuntansi dan Perpajakan untuk memenuhi kebutuhan Pasar Sehingga AAS menjadi Pioner pendidikan yang siap menjadi The TOP Of Academic di Surakarta

Sebagai perguruan tinggi swasta (PTS) yang telah lama berdiri, Akademi Akuntansi Surakarta yang dulu bernama Akademi Akuntansi dan perpajakan Bentara Indonesia (AAP Bentara Indonesia) dituntut untuk ikut berkiprah dan berperan aktif dalam menyiapkan SDM yang berkualitas dan siap bersaing di pasar tenaga kerja pada tingkatan tenaga ahli madya.

Kenyataan menunjukkan bahwa pada beberapa tahun belakangan ini, banyak perguruan tinggi yang berada di wilayah Kopertis VI Jawa Tengah, khususnya di daerah Solo Raya yang meliputi Surakarta dan Kabupaten-Kabupaten disekitar Surakarta mengalami penurunan jumlah mahasiswa yang cukup drastis, bahkan beberapa PTS terpaksa menutup kampusnya akibat sedikitnya peminat mahasiswa baru ditambah lagi kemampuan Yayasannya yang tidak memiliki sumber pendanaan diluar dari mahasiswa. Ini bisa dimaklumi karena masalah tersebut juga dialami oleh beberapa perguruan tinggi swasta yang besar maupun perguruan tinggi negeri untuk program studi tertentu yang jumlah peminatnya semakin menurun. Untuk mengatasi itu semua maka harus dilihat keinginan dan kebutuhan Konsumen dalam hal ini adalah Calon mahasiswa

\section{VISI DAN MISI}

\section{VISI}

Visi Akademi Akuntansi Surakarta adalah: Menjadi Program studi yang mengembangkan Sumber Daya Manusia yang handal, berkompetensi, berderajat di bidang Akuntansi dan Perpajakan 
MISI

Misi Akademi Akuntansi Surakarta adalah: Menyelenggaran Pendidikan dan Pelatihan yang berorentasi pada kualitas,berinovasi sehingga dapat menghasilkan Sumber Daya Manusia yang berkompetensi dan berderajat serta mampu mengaplikasikan ketrampilan dan pengetahuan di dunia global

\section{Tujuan}

Tujuan penyelenggaraan pendidikan di Akademi Akuntansi Surakarta (AAS) adalah:

1. Mengembangkan $\begin{array}{llr}\text { pendididkan } & \text { yang } & \text { mampu } \\ \text { menghasilkan } & \text { lulusan } & \text { yang }\end{array}$ profesional dibidang akuntansi dan perpajakan.

2. Mengembangkan fasilitas sarana dan prasarana pendididkan serta teknologi informasi yang berkualitas.

\section{Analisis SWOT Akademi Akuntansi Surakarta}

Analisis SWOT digunakan untuk mengetahui kekuatan apa yang dimiliki oleh organisasi dan kesempatan apa yang tersedia.dan disertai upaya memeriksa kelemahan serta ancaman yang sedang dan akan dihadapi oleh organisasi.

\section{Analisis SWOT terhadap Komponen (Mahasiswa dan Iulusan)}

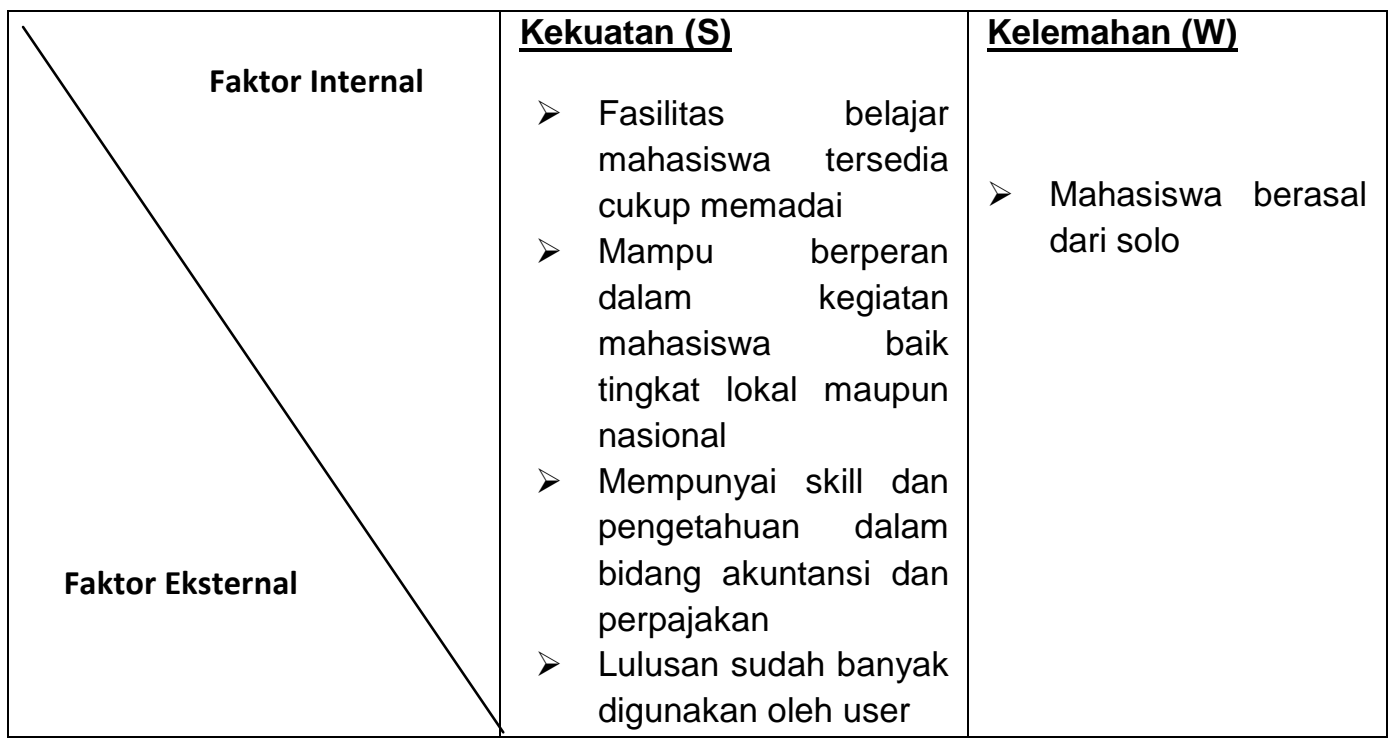




\begin{tabular}{|c|c|c|}
\hline $\begin{array}{l}\text { Peluang (0) } \\
\text { Tersedianya beasiswa } \\
\text { dari Kopertis } \\
\text { Perkembangan IPTEK } \\
\text { yang dapat diserap } \\
\text { mahasiswa tersedia } \\
\text { Terbuka luas jaringan } \\
\text { kerjasama antar } \\
\text { mahasiswa baik PTS } \\
\text { Maupun PTN }\end{array}$ & 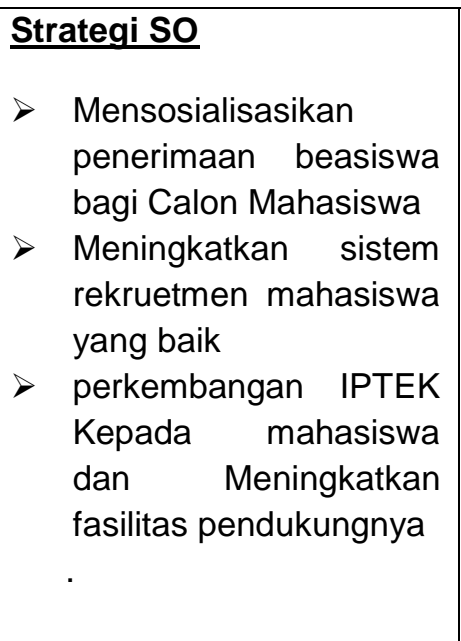 & \begin{tabular}{l} 
Strategi WO \\
\multicolumn{1}{l}{ Memperluas dan } \\
jaringan dengan \\
kerjasama dik \\
pihak eksternal baik \\
perusahaan atau \\
instansi \\
$>$ Meningkatkan \\
kemampuan \\
penguasaan IPTEK \\
mahasiswa melalui \\
kegiatan-kegiatan \\
terprogram.
\end{tabular} \\
\hline $\begin{array}{l}\text { Ancaman }(\mathbf{T}) \\
\\
\text { Persaingan yang ketat } \\
\text { bagi lulusan program studi } \\
\text { Akuntansi dan Perpajakn } \\
\text { dengan lulusan PTN }\end{array}$ & 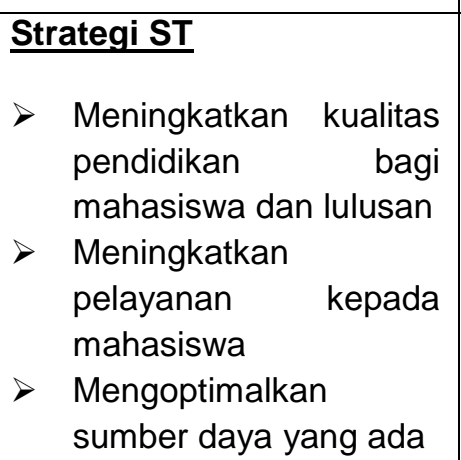 & $\begin{array}{l}\text { Strategi WT } \\
\end{array}$ \\
\hline
\end{tabular}

\section{Analisis SWOT terhadapKomponen Dosen dan tenaga Pendukung}

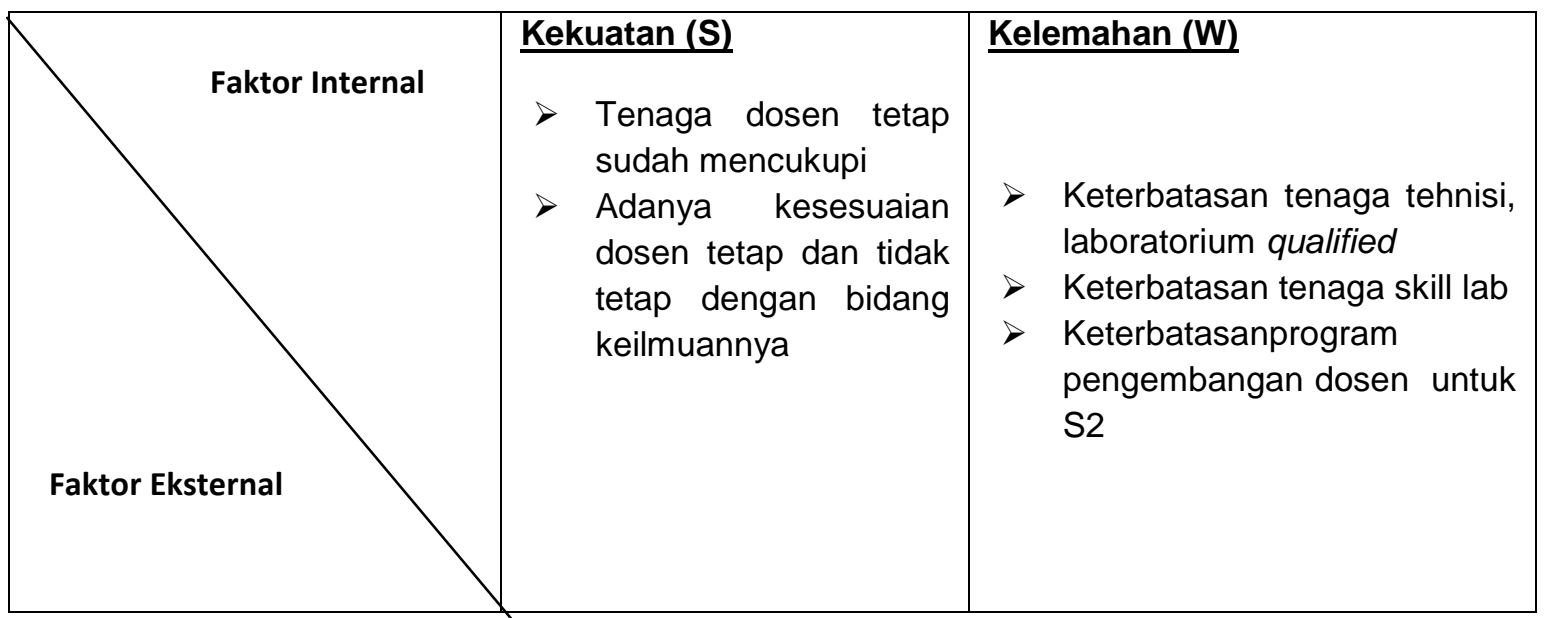




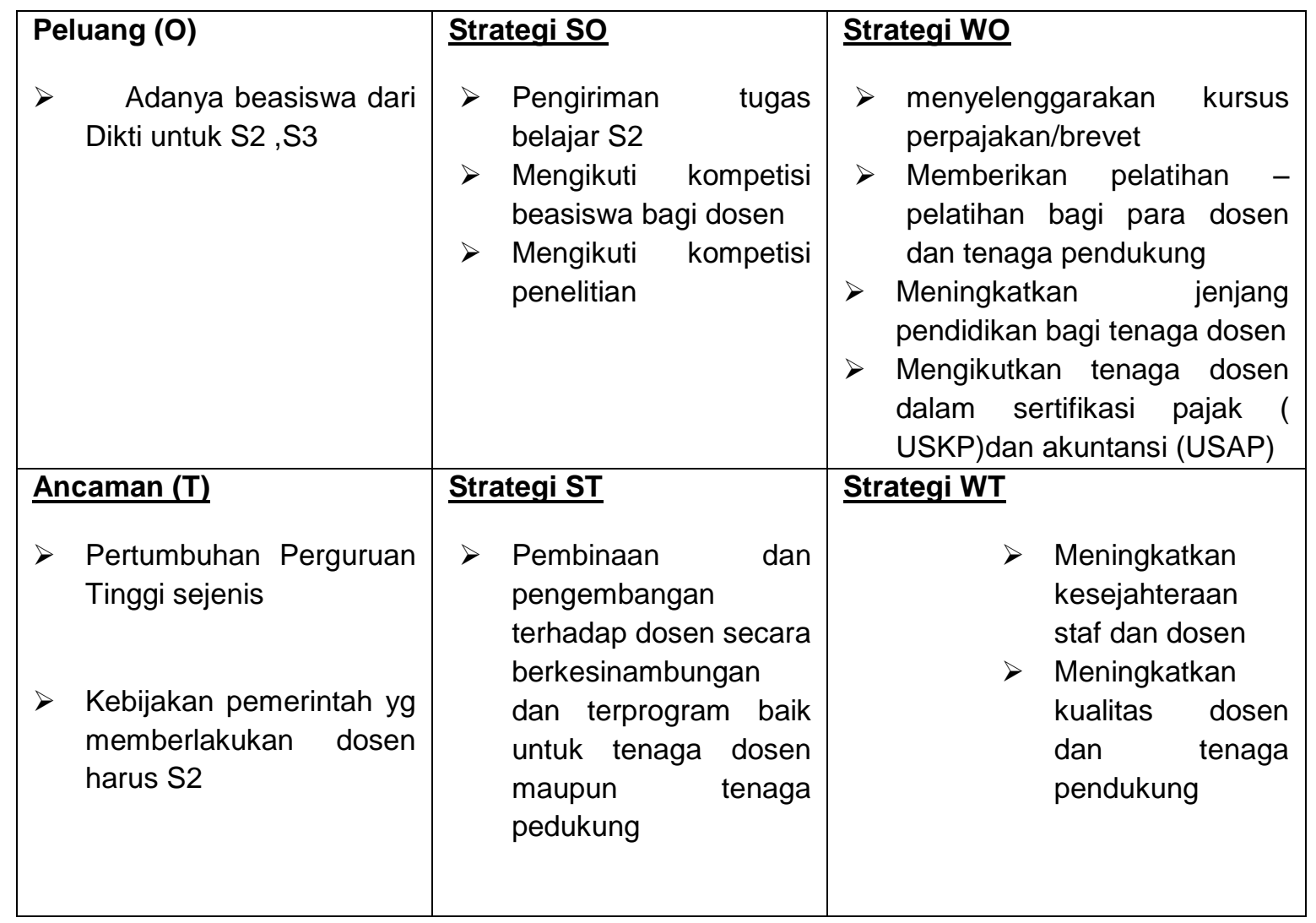

\section{Analisis SWOT terhadap Komponen Sarana dan prasarana}

\begin{tabular}{|c|c|c|}
\hline & Kekuatan (S) & Weakness \\
\hline Faktor Internal & $\begin{aligned} &> \text { Gedung milik sendiri } \\
& \text { yang dilengkapi AC \& } \\
& \text { LCD } \\
&> \text { Ruang kelas } \\
& \text { mencukupi } \\
&>\quad \begin{array}{l}\text { Memiliki alaboratorium } \\
\text { komputer }\end{array} \\
&>\quad \begin{array}{l}\text { Fasilitas ruang diskusi, } \\
\text { BEM dan HIMA }\end{array}\end{aligned}$ & $\begin{aligned} &> \text { Biaya pemeliharaan } \\
& \text { cukup besar }\end{aligned}$ \\
\hline Faktor Eksternal & & \\
\hline
\end{tabular}




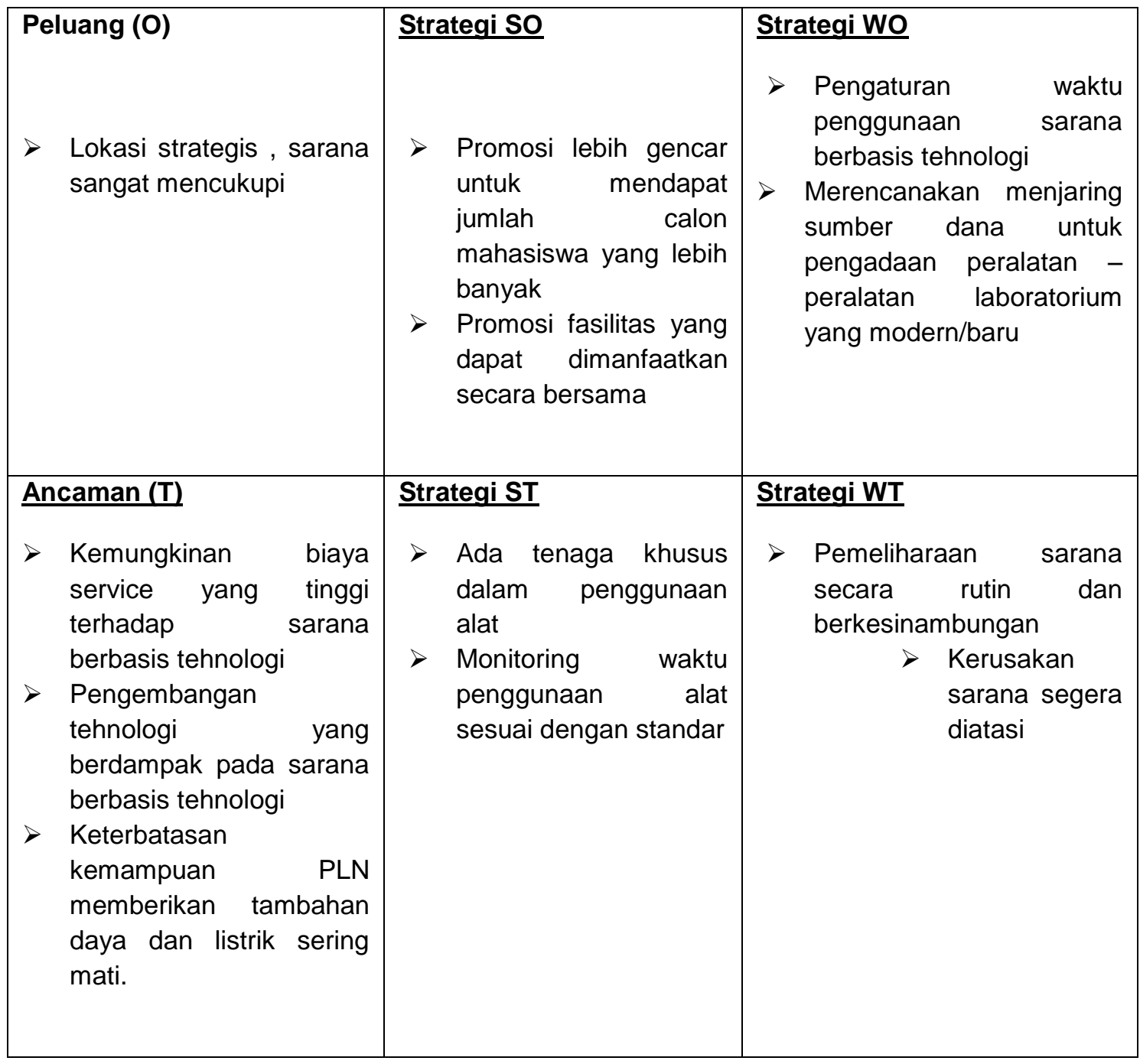

\section{Analisis SWOT terhadap Komponen(Kurikulum, Pembelajaran dan Suasana Akademik)}

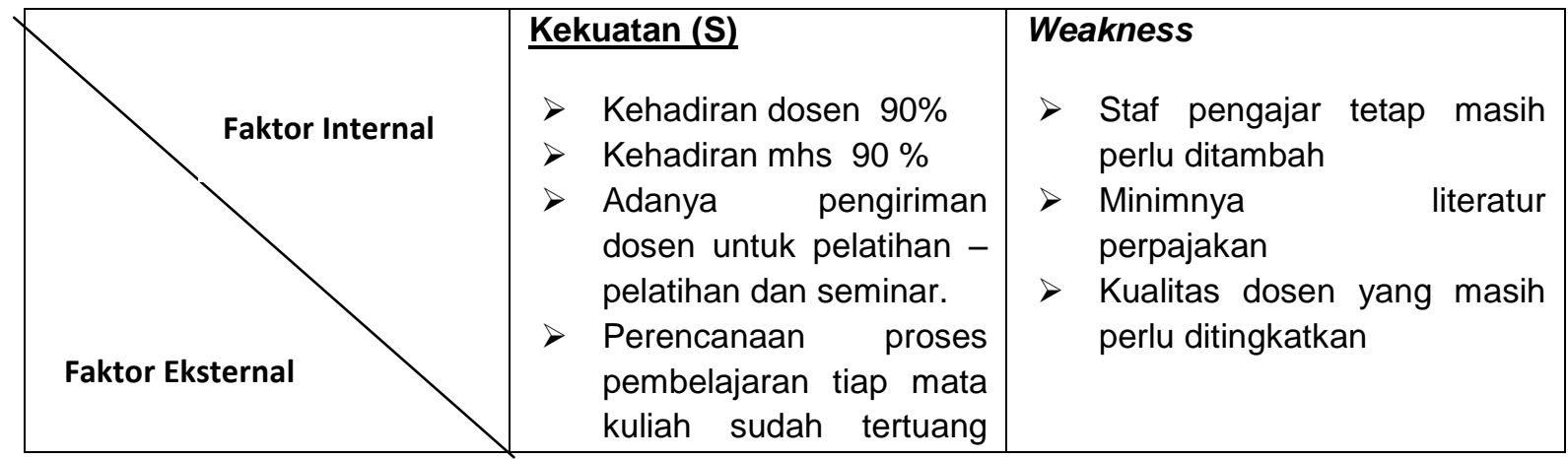

Jurnal Akuntansi dan Pajak Vol. 15 No. 01, Juli 2014 


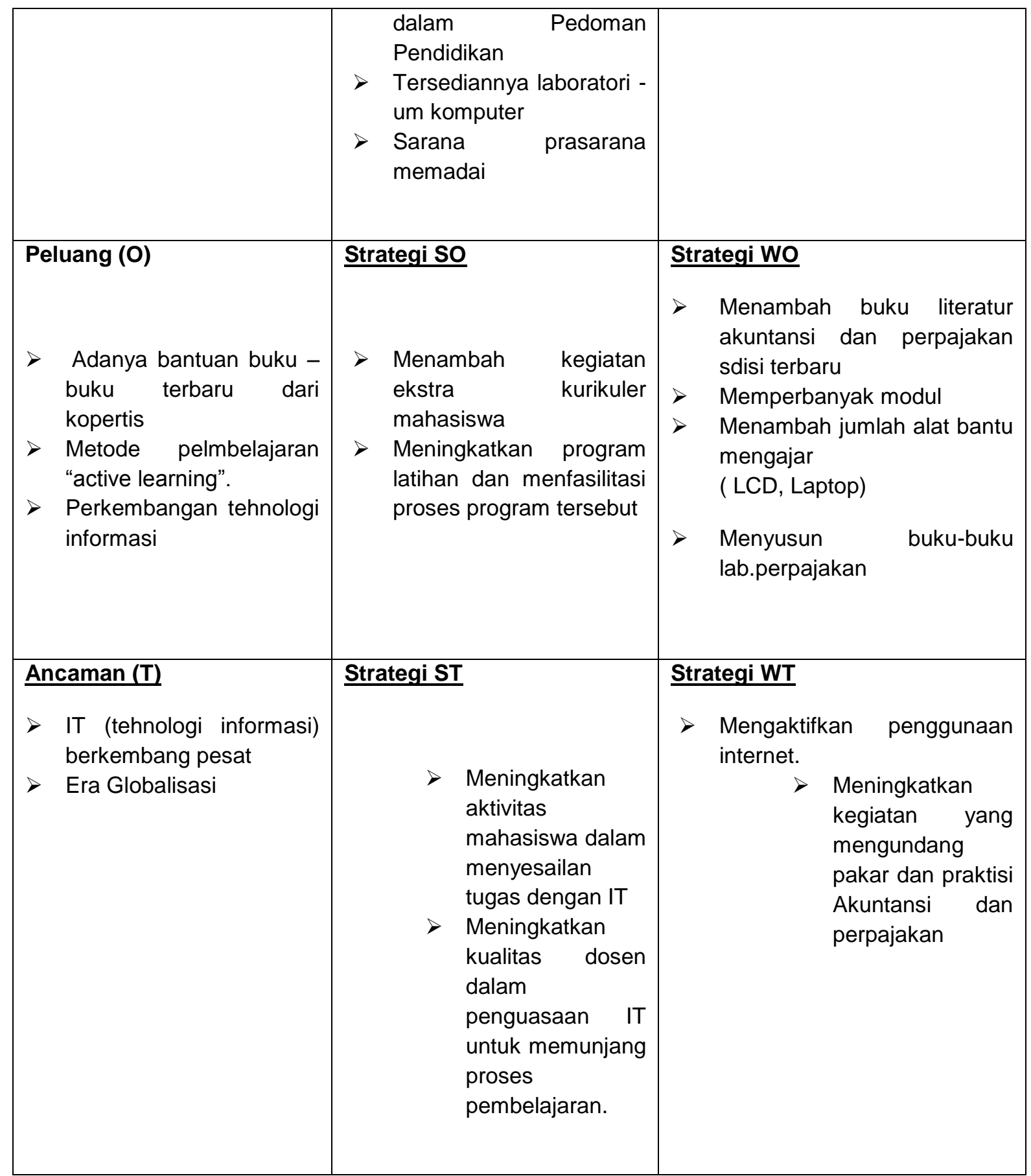


ANALISA PASAR

Hasil Analisa SWOT yang menunjukan Keragaan Kekuatan,Kelemahan,Peluang dan Ancaman yang dimiliki Akademi Akuntansi Surakarta

1. Komponen Mahasiswa dan Lulusan

a. Kekuatan: Fasilitas belajar mahasiswa tersedia cukup memadai,Mampu berperan dalam kegiatan mahasiswa baik tingkat Fasilitas belajar mahasiswa tersedia cukup memadai, Mampu berperan dalam kegiatan mahasiswa baik tingkat lokal maupun nacional, Mempunyai skill dan pengetahuan dalam bidang akuntansi dan perpajakanLulusan sudah banyak digunakan oleh user lokal maupun nasional,Mempunyai skill dan pengetahuan dalam bidang akuntansi dan perpajakan Lulusan sudah banyak digunakan oleh user

b. Kelemahannya adalah mahasiswa yang daftar masih mahasiswa sekitar Solo

c. Peluang : Tersedianya beasiswa dari Kopertis,Perkembangan IPTEK yang dapat diserap mahasiswa tersedia,Terbuka luas jaringan kerjasama antar mahasiswa baik PTS Maupun PTN

d. Ancaman : Persaingan yang ketat bagi lulusan program studi Akuntansi dan Perpajakn dengan lulusan PTN
Untuk mengatasi kelemahan dan ancaman yang di hadapi Akademi Akuntansi Surakarta Maka Sebaiknya diadakan :

a. perluasan jaringan dan kerjasama dengan pihak eksternal baik perusahaan atau instansi

b. Meningkatkan kemampuan penguasaan IPTEK mahasiswa melalui kegiatankegiatan terprogram.

c. Memperluas promosi keluar solo

d. Mengadakan Promosi dengan cara jemput bola

\section{Komponen Dosen dan tenaga Pendukung}

a. Kekuatan : Tenaga dosen tetap sudah mencukupi, Adanya kesesuaian dosen tetap dan tidak tetap dengan bidang keilmuannya

b. Kelemahan : Keterbatasan tenaga tehnisi, laboratorium qualified, Keterbatasan tenaga skill lab, Keterbatasan program pengembangan dosen untuk S2, dan S3

c. Peluang: Adanya beasiswa dari Dikti untuk S2, S3

d. Ancaman : Pertumbuhan Perguruan Tinggi sejenis, Kebijakan pemerintah yg memberlakukan dosen harus S2

Untuk mengatasi kelemahan dan Ancaman yang dihadapi Akademi Akuntansi Surakarta Maka sebaiknya diadakan : 
a. Kursus perpajakan/brevet

b. Memberikan pelatihan - pelatihan bagi para dosen dan tenaga pendukung

c. Meningkatkan jenjang pendidikan bagi tenaga dosen

d. Mengikutkan tenaga dosen dalam sertifikasi pajak ( USKP)dan akuntansi (USAP)

e. Pembinaan dan pengembangan terhadap dosen secara berkesinambungan dan terprogram baik untuk tenaga dosen maupun tenaga pedukung

f. Pengiriman tugas belajar S2

g. Mengikuti kompetisi beasiswa bagi dosen

h. Mengikuti kompetisi penelitian

\section{Komponen Sarana dan prasarana}

a. Kekuatan : Gedung milik sendiri yang dilengkapi AC \& LCD, Ruang kelas mencukupi, Memiliki laboratorium komputer ,Fasilitas ruang diskusi, BEM dan HIMA,

b. Kelemahan: Biaya pemeliharaan cukup besar, Biaya operasional besar dengan tehnologi tinggi, Monitoring program sarana dengan teknisi, Keterbatasan peralatan-peralatan lab yang baru

c. Peluang : Lokasi strategis, sarana sangat mencukupi

d. Ancaman : Kemungkinan biaya service yang tinggi terhadap sarana berbasis tehnologi. Pengembangan tehnologi yang berdampak pada sarana berbasis Jurnal Akuntansi dan Pajak Vol. 15 No. 01, Juli 2014 tehnologi, Keterbatasan kemampuan PLN memberikan tambahan daya dan listrik sering mati.

Untuk mengatasi kelemahan dan Ancaman yang dihadapi Akademi Akuntansi Surakarta Maka sebaiknya diadakan

a. Promosi lebih gencar untuk mendapat jumlah calon mahasiswa yang lebih banyak

b. Promosi fasilitas yang dapat dimanfaatkan secara bersama

c. Pengaturan waktu penggunaan sarana berbasis tehnologi

d. Merencanakan menjaring sumber dana untuk pengadaan peralatan peralatanlaboratorium yang modern/baru

e. Ada tenaga khusus dalam penggunaan alat

f. Monitoring waktu penggunaan alat sesuai dengan standar

g. Pemeliharaan sarana secara rutin dan berkesinambungan

h. Kerusakan sarana segera diatasi

\section{Komponen (Kurikulum, Pembelajaran dan Suasana Akademik)}

a. Kekuatan : Kehadiran dosen 90\%, Kehadiran mhs $90 \%$, Adanya pengiriman dosen untuk pelatihan - pelatihan dan seminar, Perencanaan proses pembelajaran tiap mata kuliah sudah tertuang dalam Pedoman Pendidikan, 
Tersediannya laboratorium computer, Sarana prasarana memadai

b. Kelemahan : Staf pengajar tetap masih perlu ditambah, Minimnya literatur perpajakan Kualitas dosen yang masih perlu ditingkatkan

c. Peluang : Adanya bantuan buku buku terbaru dari kopertis ,Metode pelmbelajaran "active learning", Perkembangan tehnologi informasi

d. Ancaman: IT (tehnologi informasi) berkembang pesat,Era Globalisasi

Untuk mengatasi kelemahan dan Ancaman yang dihadapi Akademi Akuntansi Surakarta Maka sebaiknya diadakan

a. Menambah kegiatan ekstra kurikuler mahasiswa

b. Meningkatkan program latihan dan menfasilitasi proses program tersebut

c. Menambah buku literatur akuntansi dan perpajakan edisi terbaru

d. Memperbanyak modul

e. Menambah jumlah alat bantu mengajar( LCD, Laptop)

f. Menyusun buku-buku lab.perpajakan

g. Meningkatkan aktivitas mahasiswa dalam menyesailan tugas dengan IT

h. Meningkatkan kualitas dosen dalam penguasaan IT untuk memunjang proses pembelajaran.

i. Mengaktifkan penggunaan internet.

j. Meningkatkan kegiatan yang mengundang pakar dan praktisi Akuntansi dan perpajakan
SIMPULAN :

Perilaku konsumen (Calon Mahasiswa) pada suatu produk perguruan tinggi dipengaruhi oleh berbagai Faktor antara lain Budaya, Sosial Ekonomi,Pendidikan dan sebagainya. Selain itu juga dipengaruhi oleh berbagai Atribut yang diinginkan dan dibutuhkan calon mahasiswa dalam proses produk tersebut antara lain Lokasi AAS, Sarana Pendidikan, kurikulum, Dosen ,Layanan Akademik dan biaya untuk memperoleh produk tersebut, Penelitian Susy Winarti menyimpulkan Bahwa atribut Dosen yang paling tinggi ,Dosen itu sebagai perantara ilmu sangat berpengaruh perilaku Mahasiswa dengan dosen perpengalaman,terampil dan cakap dalam mengajar akan menarik bagi Mahasiswa ,dapat dilihat di SWOT kekuatan dalam Komponen dosen dan pendukungnya .Tenaga dosen tetap sudah mencukupi, Adanya kesesuaian dosen tetap dan tidak tetap dengan bidang keilmuannya,dan sekarang sebagian sudah S2 dan Bahkan sudah ada yang S3 Dalam SWOT ada peluang untuk dosen yaitu Studi Lanjut baik S2 maupun S3 dengan beasiswa dari DIKTI Yang disusul Atribut Kurikulum,Kurikulum mempengaruhi perilaku Mahasiswa dalam memilih perguruan tinggi di AAS karena dengan susunan kurikulum yang mengikuti pangsa pasar maka akan menarik calon Mahasiswa untuk mengikuti program tersebut, kemudian atribut Sarana Pendidikan, SWOT 
Kekuatan sarana pendidikan adalah Gedung milik sendiri yang dilengkapi AC \& LCD, Ruang kelas mencukupi, Memiliki laboratorium komputer, fasilitas ruang diskusi, BEM d, Lokasi yang strategi ini juga menjadi pilihan Calon Mahasiswa, untuk AAS lokasinya sangat strategi karena bisa ditempuh dengan kendaraan umum yang bisa sampai depan AAS, meskipun banyak Mahasiswa yang menggunakan kendaraan pribadi, Biaya Kuliah yang sangat murah dibanding dengan perguruan tinggi yang lain dan tanpa uang gedung serta biaya kuliah bisa diangsur

\section{DAFTAR PUSTAKA}

Fandy Tjiptono, 2008, Strategi Pemasaran, Yogyakarta : Andi

Siti Khotimah ,2011. Perumusan strategi Perguruan Tinggi (PTS) untuk meraih keunggulan bersaing (Study Kasus pada Universitas Merdeka Malang) Thesis , Universitas Antakusuma Pangkalan Bun Kalimantan Tengah

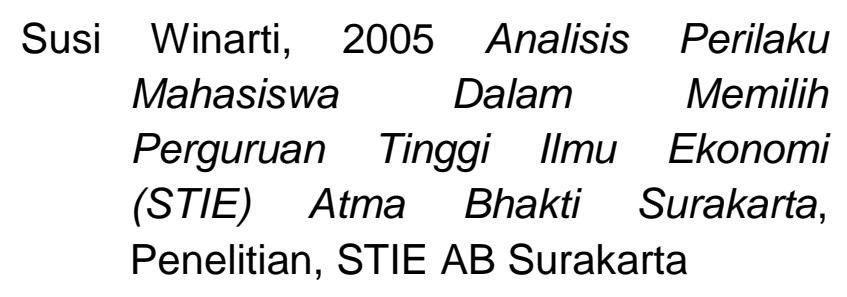

